\title{
Thermal and Mechanical Properties of Concretes with Styropor
}

\author{
B. A. Kaya, F. Kar \\ Department of Chemical Engineering, Firat University, Elazig, Turkey \\ Email: abicer@firat.edu.tr
}

Received November 2013

\begin{abstract}
In this paper waste expanded polystyrene (EPS) granulated in various proportions was added to cement and lime paste and samples were produced in order to provide heat and voice insulation and produce low-intensity concrete. Styropor, which is especially obtained as waste material in packaging industry, is used in production of samples; the purpose here was to prevent environmental pollution and produce construction material with variable cost. Hot wire method was used for measuring the thermal conductivity of the sample. A mould with the dimensions of $20 \times 60 \times$ $150 \mathrm{~mm}$ was prepared for thermal experiments and $100 \times 100 \times 100 \mathrm{~mm}$ was prepared for mechanical experiments and the mortars were cast. The samples were subjected to thermal conductivity, pressure and tensile strength and water absorption tests. The diameter of the EPS ranged from 0 to $6 \mathrm{~mm}$ and concrete involvement rate was determined as to be 0 to 70 percentages. As a result, it has been found out that in EPS-containing cement and lime binding-agent materials can be used for the following purposes: (i) production of earthquake-proof low-intensity concrete, (ii) as insulation-purpose construction material, (iii) decoration.
\end{abstract}

\section{Keywords}

Waste Styropor, Concrete Materials, Insulation

\section{Introduction}

Today styropor can be used as insulation material in buildings; it is also widely used in packaging industry. As an important waste material in terms of environmental pollution, this material has to be recycled and re-economized. Intense studies have been conducted in this area, including chemical structures of PS and EPS, usage as aggregate in low-intensity concrete construction, and its evaluation as binding agent in the production of some composite materials as well as decoration and packaging material.

Babu et al. examined the mechanical features of light concretes produced by using fly ash along with expanded polystyrene along with regular aggregate [1]. Mihlayanlar et al. investigated the thermal and mechanical characteristics of EPS insulation boards [2]. Miled et al. studied the impact of the change in the amount and dimensions of EPS found on aggregated concrete samples on the pressure resistance of the concrete [3]. Bourvard et al. worked on the physical features of high-performance concretes consisting of expanded polystyrene balls [4]. Chen studied on the characteristics of the light concrete which consists of polystyrene foam reinforced with steel fibre [5]. Babu et al. investigated the mechanical behaviours of the concretes which were mixed with silica 
fume at different rates in order to increase the resistance of low-intensity concrete consisting of EPS [6].

In this paper, the thermal and mechanical features of samples produced by granulating the styropor particles which are liberated as waste material in packaging industry using certain amounts of cement and gypsum binding agents have been examined.

\section{Expanded Polystyrene}

Expanded Polystyrene Foam (EPS) is a foam-like-closed-pored thermoplastic material, typically in white colour, obtained from polymerization of styrene monomer (Figure 1) [7].

EPS products are obtained by means of bulking and amalgamation of polystyrene particles; the bulking has used for bulking the particles and obtaining foam is "Pentane". As an organic component, pentane makes sure that several small pores are formed within the particles and then it changes places with air in a very short time during and after the production. With the liberation of pentane, inert air is trapped in the abounding ( $3-6$ billion in $1 \mathrm{~m}^{3}$ EPS depending on density) number of small pored cells. 98 percent of the material is air and the rest is polystyrene [7] [8]. Then, it is ensured that the expanded particles rested in special bunkers amalgamate with each other with the help of the steam inside the mould and that it gains the characteristics of the material. As a result of the amalgamation of particles, a continuous mass consisting of polygons combined with each other without any space, which looks like a honeycomb.

-EPS is not poisonous; it does not enter into chemical reaction under normal atmosphere conditions. It does not consist of chlorofluorocarbon (CFC), hydro chlorofluorocarbon (HCFC) and formaldehyde [9].

-EPS is not a nutrient for bacteria and fungi. EPS production consumes less energy and hence less natural resources compared to similar products.

-EPS is an infinite-life material. Once these materials are used, it is released to the nature as waste. As it is a recyclable material, and because the materials that it consists do not harm the nature and the ozone layer, it is an environmental-friend material [7]. EPS does not spoil in garbage and create greenhouse gas, and it does not pollute the air, water or the ecosystem [9]. EPS is a close-pored material. Due to its very low level of water absorption, its features do not change even if it directly contacts with water. As it does not dissolve and disintegrate in water, the pore walls are water-proof. In addition, taking into consideration the fact that EPS will not remain as totally submerged into water in any building, it can be labeled as "water-tight".

\section{Experimental Study}

The new-produced materials, which are the mixture of granule styropor, cement and binding, are subjected to some tests, such as mechanical and thermal. For mechanical tests some cubical blocks are used in dimensions of $100 \times 100 \times 100 \mathrm{~mm}$, while rectangular blocks are prepared with the dimensions $150 \times 60 \times 20 \mathrm{~mm}$ for testing the density, thermal conductivity and water absorption measurements. The samples in the moulds are presented in Figure 2.

In the samples prepared, the volumetric mixture rates of styropor were determined as $0-70$ percent for cement binding samples and 0 - 60 percent for gypsum binding-agent samples; they were cast and left to drying for the standard 28 days; then the experiments were launched. A shotherm-QTM unit (Showa Denko) which operated according to the hot wire method of DIN 51046 was used to measure the thermal conductivity of the specimens. It's magnitude and sensitivity were $0.02-10 \mathrm{Wm}^{-1} \cdot \mathrm{K}^{-1}$ and $\pm 5 \%$ on its scale respectively [10]. The measurements on three locations of each sample blocks were repeated three times to reflect the average of nine values. The thermal properties of samples are given in Table $\mathbf{1}$.
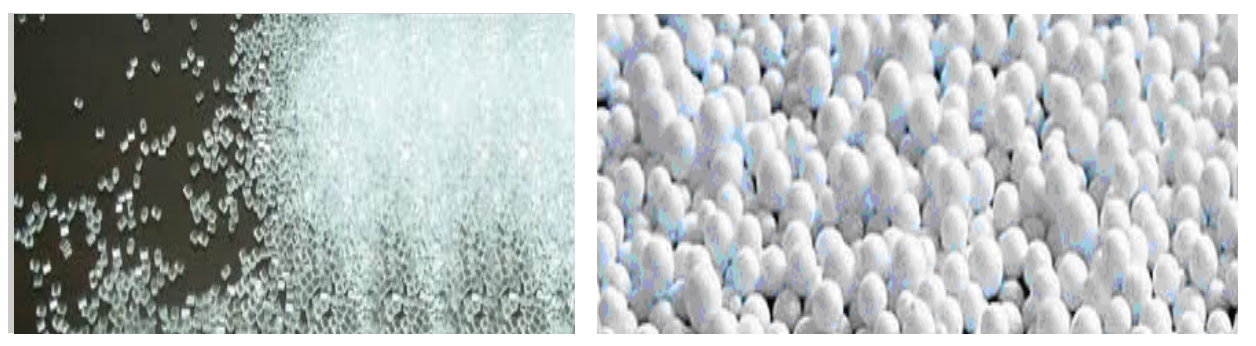

Figure 1. Polystyren and expanded polystyrene [7]. 


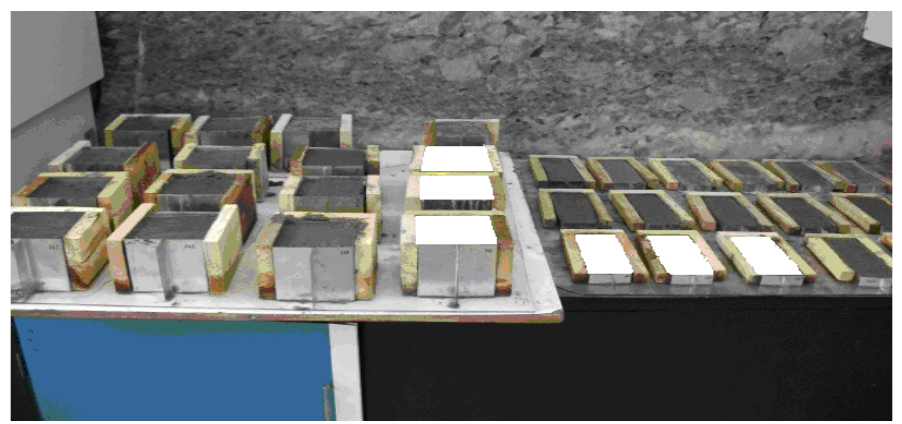

Figure 2. Rectangular and cubical blocks samples.

Table 1. Thermal conductivity and density values of sample with cement and lime.

\begin{tabular}{|c|c|c|c|c|}
\hline \multirow{2}{*}{$\begin{array}{c}\text { Styropor } \\
\text { percentage } \\
(\%)\end{array}$} & \multicolumn{2}{|c|}{ Samples with cement } & \multicolumn{2}{|c|}{ Samples with lime } \\
\hline & Density $\left(\mathrm{g} \cdot \mathrm{cm}^{-3}\right)$ & Thermal Cond. $\left(\mathrm{Wm}^{-1} \cdot \mathrm{K}^{-1}\right)$ & Density $\left(\mathrm{g} \cdot \mathrm{cm}^{-3}\right)$ & Thermal Cond. $\left(\mathrm{Wm}^{-1} \cdot \mathrm{K}^{-1}\right)$ \\
\hline 0 & 1.628 & 0.590 & 1.386 & 0.339 \\
\hline 2 & 1.617 & 0.577 & - & - \\
\hline 5 & 1.562 & 0.565 & 1.308 & 0.303 \\
\hline 8 & 1.542 & 0.552 & - & - \\
\hline 10 & 1.484 & 0.533 & 1.230 & 0.275 \\
\hline 15 & 1.468 & 0.511 & - & - \\
\hline 20 & 1.457 & 0.465 & 0.984 & 0.238 \\
\hline 25 & 1.378 & 0.436 & - & - \\
\hline 30 & 1.210 & 0.415 & 0.898 & 0.210 \\
\hline 35 & 1.171 & 0.401 & - & - \\
\hline 40 & 1.152 & 0.380 & 0.800 & 0.180 \\
\hline 45 & 1.074 & 0.356 & - & - \\
\hline 50 & 1.015 & 0.330 & 0.625 & 0.145 \\
\hline 55 & 0.976 & 0.300 & - & - \\
\hline 60 & 0.878 & 0.265 & 0.574 & 0.110 \\
\hline 65 & 0.828 & 0.235 & - & - \\
\hline 70 & 0.644 & 0.220 & - & - \\
\hline
\end{tabular}

The aim of water absorption test is to investigate the maximum amount of water uptake by the different samples. This property is important in determining the suitability of this material against freezing hazards. The critical amount of moisture is 30 percent of the total dry volume, below which the material doesn't deform on freezing. The experiments were performed according to the BS 812. Part 2 standard by keeping the specimens in water for 48 hours. Mechanical strength tests on the samples were undertaken according to the ASTM C 109-80 standard. Pressure strength and tensile strength tests were applied on each sample blocks. Those measurements were taken and listed in Table 2.

As styropor ratio increases, Thermal conductivity and density of both cement and lime binding agent samples decrease Table 1 and Figure 3 and Figure 4.

It has been found out that as the styropor rate in the samples increases, their water absorbtion, pressure strength and tensile strength values decrease Table 1 and Figures 5-7. 


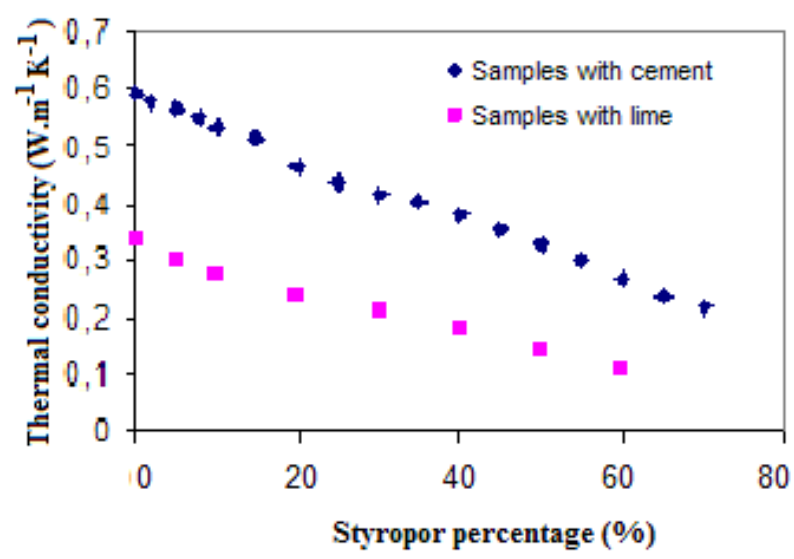

Figure 3. Thermal conductivity of samples against styropor percentages.

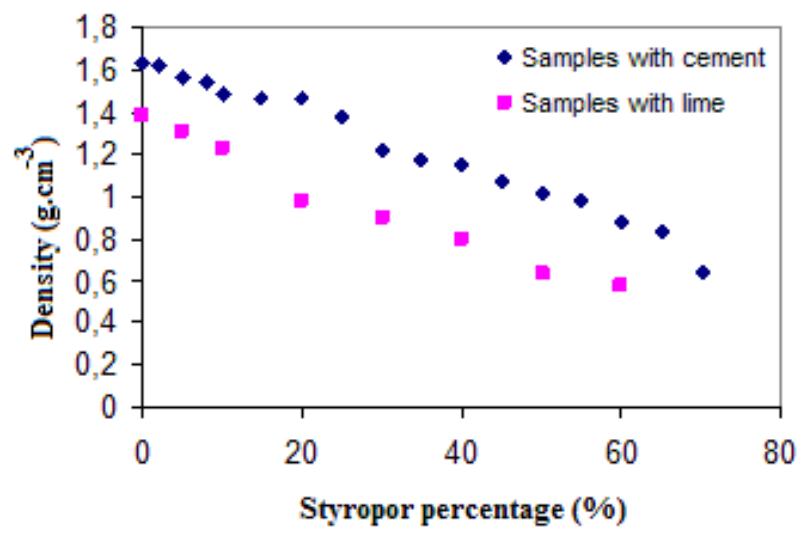

Figure 4. Density of samples against styropor percentages.

Table 2. Pressure strength, tensile strength and water absorbtion values of sample with cement and lime.

\begin{tabular}{ccccccc}
\hline \multirow{2}{*}{$\begin{array}{c}\text { Styropor } \\
\text { percentage } \\
(\%)\end{array}$} & \multicolumn{5}{c}{ Samples with cement } \\
\cline { 2 - 6 } & $\begin{array}{c}\text { Pressure strength } \\
\left(\mathrm{N} \cdot \mathrm{mm}^{-2}\right)\end{array}$ & $\begin{array}{c}\text { Tensile strength } \\
\left(\mathrm{N} \cdot \mathrm{mm}^{-2}\right)\end{array}$ & $\begin{array}{r}\text { Water absorption Pressure strength } \\
(\%)\end{array}$ & $\begin{array}{c}\text { Tensile strength } \\
\left(\mathrm{N} \cdot \mathrm{mm}^{-2}\right)\end{array}$ & $\begin{array}{c}\text { Water absorption } \\
(\%)\end{array}$ \\
\hline 0 & 36.72 & 2.12 & 22 & 7.42 & 0.96 & 24 \\
2 & 32.81 & 2.01 & 20 & - & - & - \\
5 & 31.25 & 1.96 & 18 & 6.56 & 0.90 & 22 \\
8 & 29.69 & 1.91 & 17 & - & - & - \\
10 & 28.12 & 1.86 & 16 & 5.46 & 0.82 & 20 \\
15 & 23.43 & 1.70 & 14.5 & - & - & - \\
20 & 21.87 & 1.64 & 13 & 4.29 & 0.73 & 17 \\
25 & 18.75 & 1.52 & 11 & - & - & - \\
30 & 12.50 & 1.24 & 10.5 & 2.34 & 0.54 & 14 \\
35 & 11.45 & 1.19 & 8.9 & 0.78 & 0.31 & 12.5 \\
40 & 10.93 & 1.16 & 8 & - & - & - \\
45 & 7.81 & 0.98 & 6.9 & - & - & - \\
50 & 4.68 & 0.76 & 6.2 & 0.70 & 0.30 & 8.5 \\
55 & 4.18 & 0.72 & 4 & - & - & - \\
60 & 2.34 & 0.54 & 3 & 0.62 & 0.28 & 5.5 \\
65 & 0.62 & 0.28 & 2.5 & - & - & - \\
70 & 0.46 & 0.24 & 2.0 & - & - & - \\
\hline
\end{tabular}




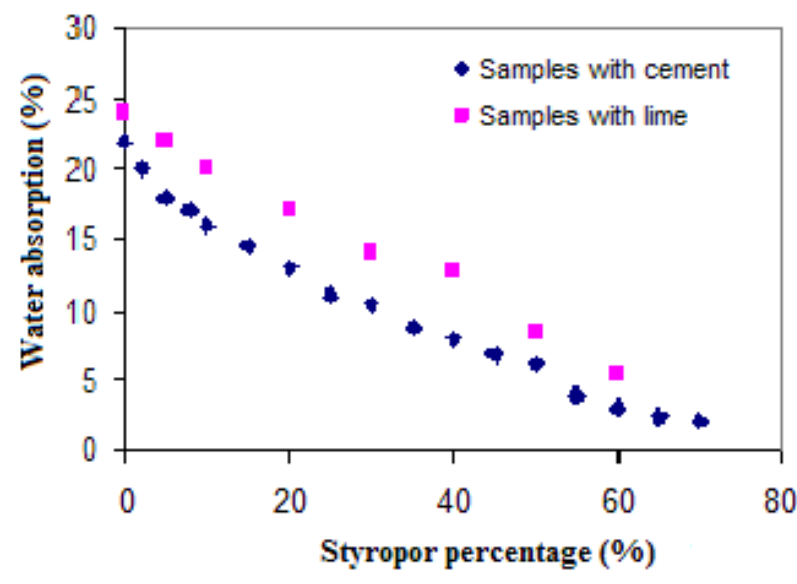

Figure 5. Water absorption of samples against styropor percentages.

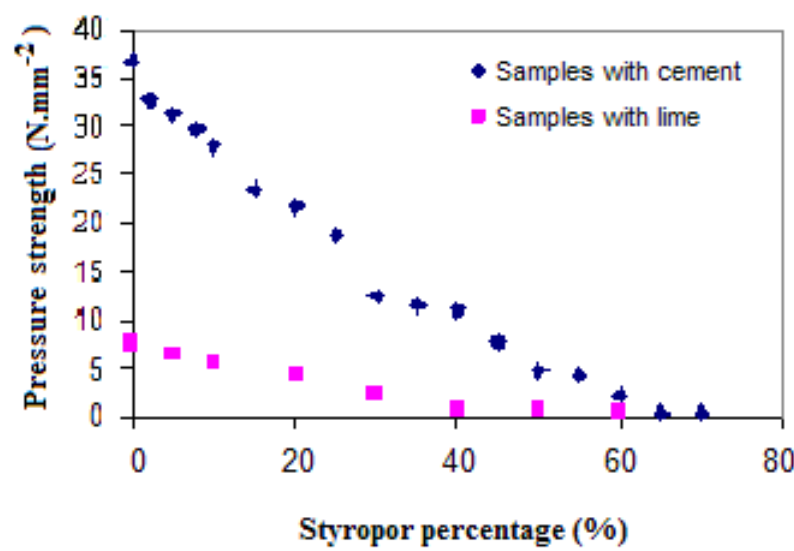

Figure 6. Pressure strength of samples against styropor percentages.

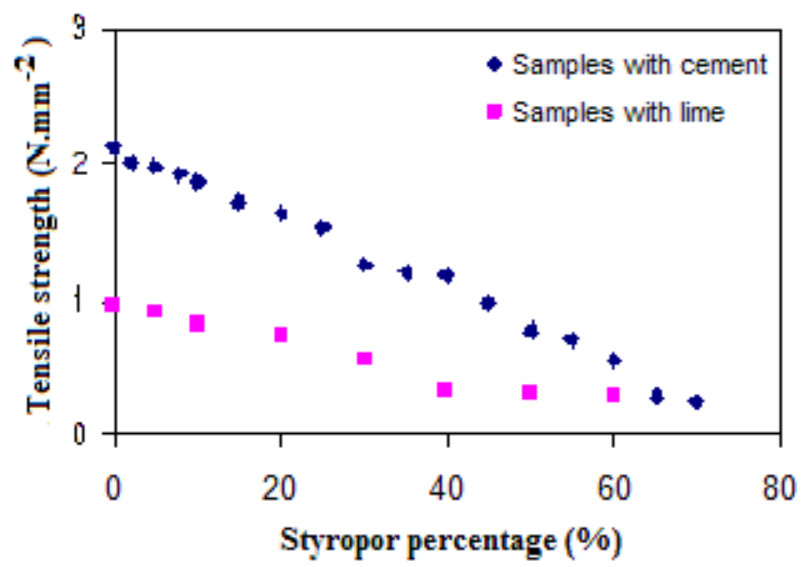

Figure 7. Tensile strength of samples against styropor percentages.

\section{Conclusions}

As the thermal conductivity of styropor is considerably low basically, the increase in styropor ratio of the samples produced by adding styropor to the mixture means a decrease in thermal conductivity coefficient, which in 
turn exerts negative impact on pressure resistance. For this reason, this type of material has the potential of being evaluated in construction elements where thermal insulation and material intensity is important.

In styropor-consisting cement and gypsum-binding agent samples, intensity decreases as styropor ratio increases. This feature can cause the decrease of vertical loads especially when cement-binding agent samples are used as concrete type and earthquake-resistance improves as the size of elements diminishes.

There are several methods for thermal insulation in buildings; choosing the appropriate material when realizing these methods are also essential. The selected thermal materials must be functional and economic and compatible with the physics of the construction.

\section{References}

[1] Babu, D.S., Babu, K.G. and Wee, T.H. (2005) Properties of Lightweight Expanded Polystyrene Aggregate Concretes Containing Fly Ash. Cement and Concrete Research, 35, 1218-1223. http://dx.doi.org/10.1016/j.cemconres.2004.11.015

[2] Mihlayanlar, E., Dilmacc, S. and Guner, A. (2008) Analysis of the Effect of Production Process Parameters and Density of Expanded Polystyrene Insulation Boards on Mechanical Properties and Thermal Conductivity. Materials and Design, 29, 344-352. http://dx.doi.org/10.1016/j.cemconres.2004.11.015

[3] Miled, K., Sab, K. and Roy, R.L. (2007) Particle Size Effect on EPS Lightweight Concrete Compressive Strength: Experimental Ivestigation and Modeling. Mechanics of Materials, 39, 222-240.

[4] Bouvard, D., Chaix, J.M., Dendievel, R., Fazekas, A., Létang, J.M., Peix, G. and Quenard, D. (2007) Characterization and Simulation of Microstructure and Properties of EPS Lightweight Concrete. Cement and Concrete Research, 37, 1666-1673. http://dx.doi.org/10.1016/i.cemconres.2007.08.028

[5] Chen, B. and Liu, J. (2004) Properties of Lightweight Expanded Polystyrene Concrete Reinforced with Steel Fiber. Cement and Concrete Research, 34, 1259-263. http://dx.doi.org/10.1016/j.cemconres.2003.12.014

[6] Babu, K.G. and Babu D.S., (2003) Behavior of Lightweight Expanded Polystyrene Concrete Containing Silica Fume. Cement and Concrete Research, 33, 755-762. http://dx.doi.org/10.1016/j.cemconres.2003.12.014

[7] http://www.yapidekor.net/Bilgiler/Genlestirilmis-Polistiren-Sert-Kopuk (20.09.2013)

[8] http://www.senapor.com.tr $(20.09 .2013)$

[9] http://www.atermit.com/tr/eps ve cevre (17.09.2013)

[10] DENKO, Showa Shotherm Operation Manual No 125-2. K.K. Instrument Products Department, 13-9, Shiba Daimon, Tokyo, 105, Japan, 1981. 